UDK 366.72:341.63

https://doi.org/10.18485/union_pf_ccr.2021.ch14

Prof. dr Maja Stanivuković*

\title{
VIŠE ISTOVRSNIH TUŽBENIH ZAHTEVA U MEĐUNARODNOJ ARBITRAŽI I ZNAČAJ OVE POJAVE ZA POTROŠAČKE SPOROVE
}

\begin{abstract}
Apstrakt: U ovom članku izložen je fenomen više istovrsnih tužbenih zahteva u međunarodnoj arbitraži koji je značajan, između ostalog, i za potrošačke sporove. Arbitražni postupak u kome je podneto više istovrsnih tužbenih zahteva često se naziva kolektivna arbitraža i može se svrstati u širi pojam višestranačke arbitraže. Mada je teško odrediti tačan broj tužbenih zahteva koji dovodi do transformacije postupka u kolektivnu arbitražu, čini se da do toga dolazi u onom trenutku kada broj tužbenih zahteva prevaziđe meru koju bi jedan ograničen broj arbitara još uvek mogao da reši u razumnom roku, vođenjem klasičnog arbitražnog postupka za svaku od tužbi. Kao glavni razlozi za kumulaciju više zahteva $u$ istom postupku navode se uštede u vremenu i troškovima, efikasnost, ujednačenost ishoda i, na kraju, bolji pristup pravdi. Kao razlozi protiv kolektivne arbitraže mogu se navesti: ograničavanje procesnih prava stranaka, nedostatak zakonskog i institucionalnog okvira, nekompatibilnost sa osnovnim načelima arbitraže i široka mogućnost zloupotreba. Uprkos potrebi da se uspostavi pravno sredstvo kolektivne zaštite potrošača u slučaju nastupanja masovnih šteta, to u Srbiji verovatno u skoroj budućnosti neće biti arbitraža.
\end{abstract}

Ključne reči: arbitraža, kolektivna arbitraža, investiciona arbitraža, potrošački sporovi.

\section{UVOD}

Počevši od svetskih ratova u dvadesetom veku, sve više je događaja izazvanih ljudskim delovanjem koji mogu da izazovu štetu ogromnih razmera. Ratovi, ekonomske krize, neodgovorno upravljanje prirodnim resursima i želja za maksimiranjem profita dovode do masovnih šteta na imovini, životu, telu i zdravlju velikog broja ljudi širom sveta. Ista pojava se može uočiti i na svetskom tržištu robe i usluga. Masovna proizvodnja i potrošnja katkada dovode do toga da veliki broj potrošača u jednoj državi istovremeno pretrpi istu ili gotovo istu štetu koju je prouzrokovao trgovac ili proizvođač iz druge države. Pojava masovnih šteta sa prekograničnim elementom, kada istovremeno nastaje veliki broj istovrsnih tužbenih zahteva, odlikuje moderno doba. ${ }^{1}$ Možemo navesti kao primer

* Redovna profesorka Pravnog fakulteta Univerziteta u Novom Sadu,

e-mail: M.Stanivukovic@pf.uns.ac.rs

1 Strong, S. I., 2013, Class, Mass, and Collective Arbitration in National and International Law, Oxford University Press, p. 3. 
skandal koji je izbio u jesen 2015. godine sa Folksvagenovim dizel automobilima. Falsifikovani izveštaji o količini štetnih emisija bili su ispisani za jedanaest miliona automobila, od kojih je osam miliona bilo prodato u raznim evropskim zemljama, a ostalo u Australiji, Brazilu, Kanadi, Kini, Indiji, Južnoj Africi, Južnoj Koreji i SAD. ${ }^{2}$

Ovaj relativno novi fenomen masovnih šteta i masovnih tužbenih zahteva stvara nove izazove u oblasti rešavanja sporova. U ovom članku bavimo se problemom više istovrsnih tužbenih zahteva u međunarodnoj arbitraži koji je značajan, između ostalog, i za potrošačke sporove, kako one unutrašnje tako i one prekogranične. Mada u takvom postupku nije reč o zaštiti kolektivnih interesa, već o kolektivnoj zaštiti pojedinačnih interesa, ipak su ova dva segmenta zaštite povezana. Posle odluke donete u postupku zaštite kolektivnih prava koja zaključuje da je neko ponašanje privrednika nezakonito i predstavlja narušavanje prava potrošača, slede pojedinačni zahtevi za naknadu štete ili za ostvarivanje nekog drugog subjektivnog prava. Ti pojedinačni zahtevi mogu se ostvarivati i kolektivnom tužbom.

Ranije su se potrošački sporovi vodili uglavnom pred sudovima i u okvirima unutrašnjeg prava. Sada je potrebno kreirati nova rešenja koja će odgovarati potrebama razvijenog međunarodnog potrošačkog prometa. Tradicionalni mehanizmi sudske zaštite nisu uvek dovoljni u tom novom kontekstu. Da li nacionalni pravosudni sistem raspolaže dovoljnim sredstvima, iskustvom i pravilima postupka da bi mogao da reši na brz i efikasan način na hiljade tužbenih zahteva? ${ }^{3}$ $\mathrm{Da}$ li će biti nepristrasan pri rešavanju o zahtevima za naknadu štete protiv domaćih korporacija kada su oštećenici rezidenti stranih država? Da li će odluke nacionalnog pravosuđa moći da se izvrše u inostranstvu?

Pošto se za rešavanje potrošačkih sporova pored pravosuđa u nekim zemljama može koristiti i arbitraža, sve više se razmišlja o opciji da se mnogobrojni istovrsni tužbeni zahtevi potrošača usmere ka arbitraži. Reč je o arbitražama u kojima se rešava veliki broj tužbenih zahteva koji su svi isti ili funkcionalno isti po činjeničnom ili pravnom osnovu, koje se vode $u$ isto vreme i pred istim arbitražnim sudom. ${ }^{4}$ Za sada, u pravnom sistemu Srbije ne postoje pravila o kolektivnoj zaštiti u sudskom postupku, a još manje u arbitraži. ${ }^{5}$ Zbog toga informaciju i inspiraciju o ovoj temi moramo tražiti u inostranstvu, u uporednom i međunarodnom pravu.

U prvom delu članka definišu se pojmovi višestranačke, klasne, masovne i kolektivne arbitraže. Definisanjem pojmova delimitira se i predmet proučavanja.

2 https://en.wikipedia.org/wiki/Volkswagen_emissions_scandal.

3 Holtzmann, H. M., 2008, Mass Claims, Max Planck Encyclopedias of International Law [MPIL], para. 4.

4 Strong, S. I., 2013, p. 5.

5 Ustavni sud je sredinom 2013. godine utvrdio da zakonska pravila o posebnom parničnom postupku za zaštitu kolektivnih prava i interesa građana nisu u skladu sa Ustavom. Odluka Ustavnog suda od 23. maja 2013. g., predmet broj IUz-51/2012, Sl. glasnik RS, br. 49/13. Vid. Karanikić Mirić, M., 2014, Kolektivna zaštita potrošača u srpskom pravu, Anali Pravnog fakulteta Univerziteta u Zenici, str. 59. 
Zatim se identifikuju opšte karakteristike kolektivne arbitraže i karakteristike potrošačkih sporova. U sledećem delu iznalaze se razlozi koji govore u prilog i protiv kolektivne arbitraže. U poslednjem delu razmatra se pitanje da li je kolektivna arbitraža moguća i poželjna u Srbiji.

\section{POJAM - KLASNA, MASOVNA ILI KOLEKTIVNA ARBITRAŽA?}

Arbitražni postupak u kome je podneto više istovrsnih tužbenih zahteva može se svrstati u širi pojam višestranačke arbitraže. ${ }^{6}$ Višestranačka arbitraža obuhvata: sporove u kojima se na strani tužioca ili tuženog javlja više lica kao suparničari, ali i sporove u kojima treće lice učestvuje kao umešač na strani tužioca ili tuženog; takođe, sporove u kojima učestvuje više od dve strane, odnosno trostrane ili višestrane sporove u kojima svaka strana brani sopstvene interese koji se razlikuju od interesa svih ostalih stranaka. ${ }^{7}$ Predmet ovog rada je samo prva grupa sporova i to samo onih u kojima se na strani tužioca javlja značajno veliki broj subjekata. Arbitraža može biti višestranačka od samog početka ili postati takva kasnije, kada se postupku pridružuje dodatna stranka ili kad se spoji više postupaka koji nisu svi između istih stranaka. ${ }^{8} \mathrm{U}$ nastavku, naša pažnja će biti usmerena ka situaciji kada se od samog početka na tužilačkoj strani javlja množina subjekata koji postavljaju isti ili sličan zahtev prema tuženom.

U međunarodnom pravu, pojam „masovni tužbeni zahtevi” (mass claims) odnosi se na situaciju kada je veliki broj lica pretrpeo štetu koja proističe iz istog značajnog istorijskog, diplomatskog ili drugog događaja koji je često vezan za ratove i promene granica. ${ }^{9}$ Sva oštećena lica podnose zahteve u ograničenom vremenskom roku. Oni su $\mathrm{u}$ istoj situaciji jer su pretrpeli istu ili sličnu štetu u isto vreme. Ideja o rešavanju ovakvih sporova arbitražom ranije je sazrela nego u unutrašnjem pravnom kontekstu. Međunarodnim ugovorima ili inicijativom međunarodnih organizacija ustanovljava se postupak za obeštećenje, koji ponekad liči na arbitražu i naziva se arbitraža. Koriste se, uz određene modifikacije, pravila o postupanju i o izvršenju arbitražnih odluka koja važe i za obične individualne zahteve. ${ }^{10}$ Prvi arbitražni postupci ove vrste organizovani su pre više

6 O višestranačkoj arbitraži kod nas pisali su: Janićijević, D., 2015, Višestranačke arbitraže problemi i najnovija dešavanja, Facta universitatis - series: Law and Politics, Vol. 13, br. 1, str. 33-43; Janićijević, D., 2009, Arbitražni sporazum kao osnov arbitražnog rešavanja višestranih i kompleksnih sporova, Zbornik radova Pravnog fakulteta u Nišu, 54, str. 81-92; Cukavac, M., 2003, Arbitraža sa više stranaka, Pravo i privreda, Vol. 40, br. 1-4, str. 79-89.

7 Stanivuković, M., 2014, Međunarodna arbitraža, Službeni glasnik, pasus 4.45.

$8 \quad$ Ibid., pasus 4.46.

9 Holtzmann, H. M., para. 1. Heiskanen, V. A., 2015, Mass Claims in ICSID Arbitration, in: Kinnear, M., Fischer, G. R. et al. (eds.), 2008, Building International Investment Law: The First 50 Years of ICSID, Kluwer Law International, p. 613.

10 Na primer, UNCITRAL-ova arbitražna pravila i Njujorška konvencija o priznanju i izvršenju stranih arbitražnih odluka. 
od dvesta godina. ${ }^{11}$ Šroko su primenjeni posle Prvog svetskog rata, ${ }^{12}$ a u novije vreme ponovo se aktuelizuju počevši od osamdesetih godina XX veka. ${ }^{13}$

Paralelno sa ovim istorijskim tokom, common law sistemi, među kojima je prednjačio američki, razvili su tokom šezdesetih godina XX veka pravila o posebnom sudskom postupku - po klasnoj tužbi (class action) ${ }^{14}$ - koja omogućavaju da se odjednom reši množina zahteva za naknadu štete uperenih protiv privrednih društava, odnosno velikih korporacija. ${ }^{15}$ Klasna ili grupna tužba služi kao instrument kojim se obezbeđuje naknada štete velikom broju pojedinaca koji imaju tužbene zahteve male vrednosti, ali takođe i kao sredstvo prevencije protiv nedozvoljenog ponašanja korporacija. ${ }^{16}$ Ovo pravno sredstvo može da se koristi i protiv stranih korporacija koje posluju preko društava kćeri u SAD. Na primer, u slučaju Folksvagena, koji je naveden na početku, američki potrošači su podneli preko petsto klasnih tužbi pred američkim sudovima protiv Volkswagen Group of America. ${ }^{17}$

Razvoj američkog sudskog procesnog prava u ovom pravcu bio je neraskidivo povezan sa arbitražom, jer su korporacije, u nastojanju da se reše opasnosti od masovnih tužbi, odnosno da onemoguće klasnu tužbu, ugovarale arbitražu sa svojim klijentima i kupcima, potencijalnim tužiocima. Smatralo se da arbitraža sama po sebi isključuje tu vrstu postupka. Umesto da uspeju u ovom nastojanju, korporacije su se početkom osamdesetih godina našle u situaciji da moraju da se brane od klasnih tužbi ne samo u sudskim postupcima nego i u arbitražnim.

11 Konkretno, 1794: Treaty of Amity, Commerce and Navigation between Great Britain and the United States (Jay treaty). Ugovorom je uspostavljena arbitražna komisija koja je donela više od 500 arbitražnih odluka u sporovima povodom zaplene pomorskih brodova. Holtzmann, H. M., 2008, para. 5 .

12 Mirovnim ugovorima zaključenim posle Prvog svetskog rata osnovani su bilateralni mešoviti arbitražni sudovi kojima je povereno u nadležnost na desetine hiljada sporova za restituciju, naknadu zbog eksproprijacije i naknadu štete nastale tokom rata. Na primer, mešoviti mađarsko-jugoslovenski arbitražni sud rešio je više od 700 takvih sporova u periodu od 1924. do 1935, mahom između mađarskih tužilaca i jugoslovenske države. Vid. opširnije: Stanivuković, M., 2020, Hungaro-Yugoslav Mixed Arbitral Tribunal (u štampi).

13 Holtzmann, H. M., 2008, para. 8.

14 Osnovu za savremeni oblik klasne tužbe predstavljaju Savezna pravila SAD o građanskom postupku iz 1966. godine - Federal Rules of Civil Procedure, Rule 23. Class Actions.

15 Ovaj institut nastao je u sudskoj praksi. Kao „okidač“ poslužilo je 300 tužbi koje je podnelo 8485 tužilaca koji su pretrpeli štetu od eksplozije teretnog broda SS Grandcamp 1947. godine u teksaskoj luci Galveston. Tužbe su podnete protiv američke države na osnovu Saveznog zakona o deliktnoj odgovornosti deliktnim zahtevima (Federal Tort Claims Act). Sud u Teksasu odlučio je da spoji sve postupke, kako se ne bi bezbroj puta ponavljalo izvođenje istih dokaza. Sud je presudio u korist tužilaca, ali je presuda preinačena po žalbi. Martinez, J., 2014, La Class action „à la française“, Le Petit Juriste, (https://www.lepetitjuriste.fr/la-classaction-a-la-francaise/). Pusey, A., 2016, April 16, 1947: Deadly ship explosions lead to first class action, ABA Journal, (https://www.abajournal.com/magazine/article/april_16_1947_deadly_ship_explosions_lead_to_first_class_action).

16 Strong, S. I., 2019, Collective Redress Arbitration in the European Union, in: International Arbitration and EU Law, Edward Elgar Publishing Ltd (anticipated 2020), p. 5, (https://papers.ssrn.com/sol3/papers.cfm?abstract_id=3396138).

17 In re: Volkswagen "Clean Diesel" Marketing, Sales Practices and Products Liability Litigation, MDL No. 2672, United States District Court, Northern District of California. 
Arbitražni sporazum koji su ugovorile sa klijentom okrenuo se protiv njih i omogućio je stvaranje „klasne“ arbitraže. ${ }^{18}$

Američka autorka Stacie Strong, koja je objavila monografiju o ovoj temi, ${ }^{19}$ razlikuje klasnu, masovnu i kolektivnu arbitražu. Pod klasnom arbitražom, ona podrazumeva uvođenje elemenata sudske klasne tužbe koja postoji u američkom građanskom procesnom sistemu u oblast arbitraže. U takvoj arbitraži postoji jedan imenovani tužilac koji podnosi tužbeni zahtev u ime grupe neimenovanih tužilaca kao njihov predstavnik. ${ }^{20}$ Zbog toga se američka klasna arbitraža svrstava u „Zastupničke" postupke. Svojstvo predstavnika grupe ili klase mora se ustanoviti preliminarnom odlukom suda ili arbitara, a pripadnici grupe imaju pravo da se izuzmu (opt-out) iz postupka i da sami u svoje ime pokrenu arbitražu. Međutim, ako ne iskoriste priliku da se izuzmu, smatra se da su pristali da budu tužioci i bez izričite saglasnosti. Konačna odluka doneta u klasnoj arbitraži obavezuje sve pripadnike klase koji se nisu izuzeli. Klasa se definiše preliminarnom odlukom suda ili arbitara. Potencijalni pripadnici klase moraju biti obavešteni na odgovarajući način o postojanju klasne arbitraže i o prilici da se izuzmu iz postupka. Najčešće inicijativa za podnošenje tužbe potiče od advokatske kancelarije koja prikuplja podatke o potencijalnim oštećenicima čim sazna za neki štetni događaj i pokreće postupak u ime predstavnika tužilaca. Posle odluke Vrhovnog suda SAD u predmetu Green Tree Financial Corp. v. Bazzle (2003), kojom je potvrđeno ovlašćenje arbitražnog suda da sam odluči da li u konkretnom slučaju treba dozvoliti klasnu arbitražu, poznate američke arbitražne institucije donele su dopunske pravilnike o klasnoj arbitraži ${ }^{21}$ Karakteristično je za te pravilnike da gotovo u potpunosti preuzimaju pravila o klasnoj tužbi iz Saveznih pravila SAD o građanskom postupku. ${ }^{22} \mathrm{U}$ klasnim postupcima tužiocima na raspolaganju stoji i sistem prikupljanja dokaza, tzv. discovery koji se primenjuje $\mathrm{u}$ američkom građanskom procesnom pravu.

O klasnoj tužbi u američkom građanskom sudskom i arbitražnom postupku pisao je kod nas Dejan Janićijević. ${ }^{23}$ On objašnjava da klasni sporovi nastaju kada se istovetnim ponašanjem određenog pravnog subjekta povrede prava velikog broja lica. ${ }^{24} \mathrm{U}$ američkom pravnom sistemu ova vrsta tužbe je našla široku primenu u oblasti zaštite prava potrošača i odgovornosti za proizvode. ${ }^{25}$ Najčešći tužbeni zahtev u klasnoj tužbi je zahtev za naknadu štete.

18 Kao prva klasna arbitraža pominje se predmet Keating v. Superior Court iz 1982. godine. Strong, S. I., 2013, p. 7.

19 Vid. fn. 1.

20 Strong, S. I., 2013, p. 6.

21 American Arbitration Association, Supplementary Rules for Class Arbitrations, October 8, 2003; JAMS Class Action Procedures, May 1, 2009; i National Arbitration Forum Class Procedures 2007.

22 Federal Rules of Civil Procedure, Rule 23. Class Actions.

23 Janićijević, D., 2006, Rešavanje tzv. klasnih sporova u parničnom i arbitražnom postupku, Zbornik radova Pravnog fakulteta u Nišu, 47, str. 111-122.

24 Ibid.

25 Pored ovih oblasti, autor pominje i ostvarivanje naknade štete u oblasti nelojalne konkurencije, povrede ljudskih prava i propisa o zaštiti životne sredine. Janićijević, D., 2006, str. 111. U statistici Američkog udruženja za arbitražu, 37\% klasnih arbitražnih sporova bili su u oblasti zaštite potrošača. Strong, S. I., 2013, p. 22. 
Procvat klasne arbitraže u SAD dogodio se u prvoj deceniji XXI veka, kada je samo Američko udruženje za arbitražno pravo administriralo, na primer, više od 300 klasnih arbitraža. Međutim, od 2010. njihov broj opada, zbog odluka Vrhovnog suda SAD kojima je potvrđeno da strana u arbitražnom sporazumu može da se odrekne prava na pokretanje klasne arbitraže, posebno u kontekstu potrošačkih ugovora, ${ }^{26}$ što su korporacije aktivno zagovarale i uredno unosile u svoje adhezione ugovore. ${ }^{27}$ Vrhovni sud SAD je 2019. otišao i korak dalje: zauzeo je stav da klasna arbitraža mora biti izričito predviđena u arbitražnom sporazumu da bi mogla da se sprovede. ${ }^{28}$

Druga vrsta je masovna arbitraža i kao prvu takvu arbitražu autorka Stacie Strong izdvaja investicionu arbitražu u predmetu Abaclat v. Argentine Republic ${ }^{29}$ (2007-2016) u kojoj je prvobitno podneto preko 180.000 tužbi ${ }^{30}$ mada se njihov broj do sklapanja poravnanja, 2016. godine, sveo na oko 50.000. ${ }^{31}$ Arbitražni sud je sam kvalifikovao ovu arbitražu kao „masovni postupak“ (mass proceeding) i definisao je na sledeći način: „veliki broj tužilaca koji se pojavljuju zajedno kao jedna masa" ${ }^{32}$ Predmet spora bio je tretman duga Argentine po državnim obveznicama. Masa obveznica prodata je preko italijanskih banaka malim investitorima u Italiji. Spor je nastao kada je Argentina, pogođena velikom ekonomskom krizom, pokušala da poveriocima, vlasnicima državnih obveznica, nametne dogovor o restrukturiranju duga. U ovom predmetu, arbitražni sud je po mišljenju Stejsi Strong razvio novu formu arbitraže sa velikim brojem istovrsnih tužbenih zahteva koja se razlikuje od klasne arbitraže u američkom pravu po tome što joj nedostaje zastupnička komponenta. ${ }^{33}$ Ova nova masovna arbitraža zasnovana je teorijski na međunarodnim ugovorima (na bilateralnom investicionom ugovoru između Italije i Argentine i ICSID konvenciji), mada oni ne sadrže odredbe o višestranačkoj arbitraži, a još manje o masovnim tužbama. ${ }^{34}$

26 Posebno je značajna u tom smislu bila odluka doneta 27. aprila 2011. g., u predmetu AT\&T Mobility LLC v. Concepcion, 563 US 333 (2011), Supreme Court of the United States.

27 Strong, S. I., 2019, p. 5.

28 Supreme Court of the United States, Lamps Plus, Inc., et al. v. Varela, Case no. 17-988, decision of April 24, 2019.

29 ICSID, Abaclat and others v. Argentine Republic, Case No. ARB/07/05, Decision on Jurisdiction and Admissibility of 4 August 2011.

30 Abaclat and others v. Argentine Republic, pasus 294.

31 Thomson, D., 2016, Argentina settles Abaclat sovereign bond claim, Global Arbitration Review, (https://globalarbitrationreview.com/article/1035101/argentina-settles-abaclat-sovereign-bond-claim).

32 Abaclat and others v. Argentine Republic, pasus 480.

33 Međutim, vid. donekle drukčiji stav u tekstu: Radicati di Brozolo, L. G., Ponzano, F., Representative Aspects of „Mass Claim“ Proceedings in Investor-State Arbitration, in: Hanotiau, B. and Schwartz, E. A. (eds.), 2016, Class and Group Actions in Arbitration, Dossiers of the ICC Institute of World Business Law, ICC Pub. No. 771, Vol. 14, p. 127.

34 Kasnije su protiv Argentine pokrenuta još dva masovna postupka: ICSID, Ambiente Ufficio S.p.A. and others v. Argentine Republic, Case No. ARB/08/9 (sa 90 tužilaca) i ICSID, Giovanni Alemanni and Others v. The Argentine Republic, Case No. ARB/07/8 (sa 74 tužioca). Protiv Kipra je pokrenut spor ICSID, Theodoros Adamakopoulos and others v. Republic of Cyprus, Case No. ARB/15/49 u kome se pojavljuju skoro 954 tužioca. U februaru 2020. godine arbitražni sud je većinom glasova odlučio da je nadležan. 
Masovna investiciona arbitraža razlikuje se od ranijih postupaka za rešavanje masovnih pravnih zahteva u međunarodnom pravu po tome što su svi tužbeni zahtevi koncentrisani i objedinjeni u jednom jedinstvenom postupku. Za razliku od toga, masovni privatnopravni zahtevi za restituciju, naknadu za eksproprisanu imovinu i naknadu štete, koji su se javljali na primer posle Prvog svetskog rata, ili posle iranske krize, ${ }^{35}$ rešavani su u više uzastopnih pojedinačnih arbitraža koje su bile vođene pred stalnim arbitražnim sudovima posebno osnovanim za tu svrhu. Arbitražni sudovi su bili specijalno ustanovljeni međunarodnim ugovorima, a pojedinačni postupci koji su vođeni pred njima često su bili veoma slični i rešavani su primenom istih ili sličnih pravila. ${ }^{36}$

Međutim, kako ističe Kabra, pojam „masovni tužbeni zahtevi“ (mass claims) ne odnosi se na neku posebnu formu postupka, već samo na određene tipične karakteristike postupka koje su zajedničke takvim predmetima. On izdvaja dve takve karakteristike: broj tužilaca i sličnost tužbenih zahteva. ${ }^{37}$

Pod kolektivnom arbitražom, Stejsi Strong podrazumeva sve ostale vrste masovnih postupaka koji nisu zasnovani na međunarodnim ugovorima, a ne liče ni na američku klasnu arbitražu. ${ }^{38}$ Kolektivna arbitraža se na primer razvila u Nemačkoj, posle odluke Bundesgerichtshofa (Saveznog suda) iz 2009. ${ }^{39}$ da su sporovi između članova privrednih društava arbitrabilni. Nemačka arbitražna institucija DIS je zatim donela novi pravilnik u kome se razrađuje postupak za rešavanje kolektivnih sporova članova privrednih društava. ${ }^{40}$ Postupak je ograničen na ortačka društva i društva sa ograničenom odgovornošu. ${ }^{41}$

Kolektivna arbitraža predviđena je i u Španiji i to upravo za potrošačke sporove (bez inostranog elementa). Španski zakon $231 / 2008,{ }^{42}$ kojim se reguliše sistem potrošačke arbitraže, sadrži u petom poglavlju poseban postupak za kolektivnu potrošačku arbitražu. Ona se definiše na sledeći način: „Predmet kolektivne potrošačke arbitraže je rešavanje u jednoj potrošačkoj arbitraži onih sporova (conflicts) koji bi, na osnovu istih činjeničnih pretpostavki, imali moć da povrede kolektivne interese potrošača i korisnika i koji imaju dejstvo na određen ili odrediv broj takvih lica. “43

U domaćoj doktrini, Marija Karanikić razlikuje mehanizam kolektivne zaštite većeg broja pojedinačnih interesa, odnosno subjektivnih prava i postupak

35 Tribunal za iransko-američke zahteve sa sedištem u Hagu, ustanovljen je Alžirskom deklaracijom o rešavanju zahteva vlade SAD i vlade Islamske Republike Iran od 19. januara 1981. i doneo je više od 500 arbitražnih odluka. Vid. npr. pravila mađarsko-jugoslovenskog MAT-a.

37 Kabra, R., 2015, Has Abaclat v Argentina left the ICSID with a "mass"ive problem?, in: Park, W. W. (ed.), Arbitration International, Oxford University Press, Vol. 31, Issue 3, pp. 426- 428.

38 Strong, S. I., 2013, p. 17.

39 Federal Court of Justice of Germany, BGH - II ZR 255/08, decision of 6 April 2009.

40 DIS Supplementary Rules for Corporate Law Disputes, 15 September 2009, (http://www.disarb.org/en/16/rules/dis-supplementary-rules-for-corporate-law-disputes-09-srcold-id15).

41 Strong, S. I., 2019, p. 23.

42 Real Decreto-ley 231/2008 de 15 de febrero, por el que se regula el Sistema Arbitral de Consumo, Boletín Oficial Del Estado, lunes 25 de febrero de 2008, Número 48, Página 11072, arts 56-62.

43 Strong, S. I., 2013, p. 363. 
za zaštitu kolektivnog interesa koji se definiše kao transindividualni, zajednički interes ili kolektivno pravo. ${ }^{44} \mathrm{U}$ prvom slučaju reč je o vođenju jednog postupka o pravima i obavezama više stranaka. Njen je stav da se kolektivna zaštita većeg broja pojedinačnih interesa u parničnom postupku može ostvariti na osnovu pravila o spajanju parnica protiv istog tuženika radi zajedničkog raspravljanja, ako se time ubrzava postupak ili umanjuju troškovi. Drugim rečima, za rešavanje više istovrsnih tužbenih zahteva u parničnom postupku nisu potrebna posebna pravila, već se mogu koristiti postojeća pravila. Ovi zaključci mogli bi se primeniti i na arbitražu. Marija Karanikić pod ovaj vid zaštite svrstava i američku klasnu ili grupnu tužbu. Grupna tužba postavlja kondemnatorni zahtev i ima kompenzatorni cilj. ${ }^{45}$ Nasuprot tome, zaštita kolektivnih interesa ima prevashodno preventivni cilj. Tužbeni zahtev usmeren je na utvrđivanje da je došlo do povrede propisa i na obavezivanje tuženog da se uzdrži od radnji kojima se čini povreda. Zaštita kolektivnih interesa po pravilu ima zastupnički karakter - kao tužilac se pojavljuje ovlašćena organizacija (na primer organizacija za zaštitu potrošača) ili državni organ. Autorka primećuje da odluka o utvrđenju da je došlo do povrede kolektivnog prava može u daljem toku stvari predstavljati osnov za pokretanje postupaka za naknadu štete koje će pokretati individualni subjekti. Međutim, ništa ne sprečava te subjekte da posegnu za kolektivnom zaštitom svojih interesa.

Shodno tome, navedene karakteristike pojedinih vrsta postupaka se mešaju i ne mogu se dosledno sprovesti, kao što to pokazuju primeri iz austrijskog i francuskog prava.

U Austriji, ne postoji grupna tužba kao takva. Međutim, u sudskoj praksi razvijen je jedan oblik kolektivnog ostvarenja prava koji se primenjuje već dvadesetak godina u oblasti zaštite potrošača i naziva se „klasna tužba na austrijski način". Postupak je sledeći: svi potencijalni tužioci koji smatraju da imaju pravo na isti ili sličan zahtev prema tuženom, ustupaju svoja potraživanja nekom licu ili udruženju, po pravilu organizaciji za zaštitu potrošača, koja je voljna da se pojavi kao tužilac. Ustupanje se obavlja samo formalno, jer ustupioci zadržavaju pravo na udeo u raspodeli iznosa koji eventualno bude ostvaren u parnici. Potrošačka organizacija zatim pokreće jedan jedinstveni parnični postupak protiv tuženog u kome se utužuju sva potraživanja koja su joj prethodno ustupljena. Budući da je zbirni iznos tužbenih zahteva prilično visok, potrošačka organizacija uspeva da od trećih lica pribavi sredstva za finansiranje troškova spora. Obično se sve završi poravnanjem. Pravni osnov za podnošenje tužbe nalazi se u paragrafu 227 ZPO koji omogućava kumulaciju više istovrsnih tužbenih zahteva protiv istog tuženog. Prema austrijskom ZPO, jedini uslovi za podnošenje ove tužbe su da je sud nadležan da odlučuje o svim istaknutim tužbenim zahtevima i da je za sve zahteve određena ista vrsta postupka. U sudskoj praksi dodata su još dva uslova: da svi zahtevi moraju biti zasnovani na sličnom činjeničnom i pravnom osnovu i da se po svim zahtevima

44 Karanikić Mirić, M., 2014, str. 67-83.

45 Grupna tužba „sadrži zahtev za naknadu štete koji veliki broj oštećenika iz istog štetnog događaja usmerava prema istom odgovornom licu." Karanikić Mirić, M., 2014, str. 67-68. 
postavljaju slična činjenična i pravna pitanja. ${ }^{46}$ Jasno je da bi se austrijska tužba mogla okarakterisati i kao klasna i kao kolektivna.

U Francuskoj, donet je Zakon od 17. marta 2014. godine (la loi Hamon) ${ }^{47}$ koji u čl. 423-1 -423-26 ustanovljava grupnu tužbu za zaštitu prava potrošača. Ovaj zakon predviđa da udruženje za zaštitu potrošača koje zastupa potrošače na nacionalnom nivou i priznato je kao ovlašćeno u Zakoniku o zaštiti potrošača ${ }^{48}$ može pokrenuti građanski sudski postupak u cilju ostvarivanja naknade za individualne štete koje su pretrpeli potrošači koji se nalaze u identičnoj ili sličnoj situaciji usled propuštanja istog profesionalca da izvrši svoje ugovorne i zakonske obaveze u oblasti prodaje robe i pružanja usluga ili usled prakse tog profesionalca koja je suprotna pravilima o konkurenciji. Tužba se može odnositi samo na naknadu imovinske štete koju su potrošači pretrpeli (a ne na naknadu moralne štete, štete nastale usled telesne povrede ili štete nanete životnoj sredini). ${ }^{49}$ Predviđen je postupak u tri etape. U prvoj, sud odlučuje o dopuštenosti tužbe, o odgovornosti profesionalca, određuje opseg grupe, određuje štetu koja se može naknaditi i njen iznos. Ukoliko donese odluku da postoji odgovornost, određuje rok koji se kreće od dva meseca do šest meseci i mere publiciteta o kojima će zainteresovani potrošači biti obavešteni. Druga etapa služi za pristupanje grupi. Samo potrošači koji se izričito pridruže grupi imaju pravo da ostvare naknadu štete i samo njih obavezuje odluka suda (postupak, dakle, ima opt-in karakter, za razliku od američke klasne tužbe). Zatim profesionalac isplaćuje članovima grupe naknadu u iznosu i rokovima koji su određeni u presudi suda. U trećoj etapi rešavaju se eventualni sporovi koji mogu nastati na osnovu implementacije presude donete u prvoj etapi. Sudija jednom jedinstvenom presudom odlučuje o svim spornim zahtevima za naknadu. ${ }^{50}$

Radicati di Brozolo i Poznano smatraju da je opšti i neutralan termin za sve vrste postupaka koje podrazumevaju pluralitet tužilaca „kolektivni postupak” i „kolektivna tužba“ “51 Shodno tome, čini se da je najpogodniji termin za potrebe ovog članka „kolektivna arbitraža“, pa ćemo ga, dosledno tome, dalje koristiti za označavanje arbitraže u kojoj se javlja više tužilaca sa istovrsnim zahtevom.

46 Klauser, A., 2019, The Essentials of Class Action in Austria, Lexology, (https://www.lexology. com/library/detail.aspx?g=91e0cfc9-db17-467b-aeae-3ffbd9802102).

47 La loi $n^{\circ}$ 2014-344 du 17 mars 2014 relative à la consommation, (https://www.legifrance. gouv.fr/affichTexte.do? cidTexte=JORFTEXT000028738036\&dateTexte=\&categorieLien $=$ id\#JORFSCTA000028738116).

48 Zakon ovlašćuje samo šesnaest potrošačkih organizacija da pokrenu ovakve tužbe. Martinez, J., 2014, p. 5.

49 Ibid., p. 3. La loi nº 2014-344 du 17 mars 2014 relative à la consommation, art. 423-1.

50 Ibid., član 423-23.

51 Radicati di Brozolo, L. G., Ponzano, F., 2016. Treba u ovom kontekstu ukazati na činjenicu da je većina arbitražnog veća u predmetu Abaklat i drugi protiv Argentine konstatovala da ova arbitraža spada u širu kategoriju „kolektivnih postupaka“ (collective proceedings). Abaclat and others v. Argentine Republic, pasus 482. O vrstama kolektivnih postupaka videti pasus 483 ove odluke. 


\section{OPŠTE KARAKTERISTIKE KOLEKTIVNE ARBITRAŽE}

Kao što je rečeno, kolektivnu arbitražu karakteriše izuzetno veliki broj tužilaca u jednom istom sporu koji se nalaze u istoj ili sličnoj situaciji. Ove dve odlike se u američkoj teoriji o klasnim tužbama označavaju kao „brojnost“ $i$ „sličnost" (numerosity and commonality). ${ }^{52}$ Kolektivna arbitraža može po karakteru biti zastupnička i nezastupnička. Arbitražni postupak nije zastupnički ako svaki tužilac podnosi tužbu u svoje ime. ${ }^{53}$

Kolektivni postupci služe za ostvarivanje dva interesa. Jedan je temporalni interes, jer će se rešavanje svih zahteva ostvariti istovremeno i za kraće vreme nego što bi to bio slučaj kada bi se postupci vodili odvojeno. Drugi je ekonomski interes, jer se troškovi spora dele na veliki broj stranaka. ${ }^{54}$

Heiskanen ističe u prvi plan da je za ovu vrstu arbitraže karakteristično da svi tužbeni zahtevi imaju isti činjenični osnov. On navodi kao primer ekonomsku krizu u Argentini i smatra da je svih pedeset i više investicionih arbitraža pokrenutih protiv Argentine posle 2001. godine, a ne samo tri predmeta u kojima su podnete kolektivne tužbe ${ }^{55}$ bilo u stvari povezano istim činjeničnim osnovom, pomenutom ekonomskom krizom. Po njemu, bilo bi optimalno da su svi ovi zahtevi rešeni u jednom postupku, jer su se mogli izbeći veliki troškovi i protivrečne odluke. Međutim, u ICSID-ovom sistemu nedostaju pravila o obaveznom spajanju postupaka. ${ }^{56}$

Teško je odrediti tačan broj tužbenih zahteva koji dovodi do transformacije postupka u kolektivnu arbitražu. Kao što ističe Kabra, do transformacije dolazi u onom trenutku kada broj tužbenih zahteva prevaziđe meru koju bi jedan ograničen broj arbitara još uvek mogao da reši vođenjem klasičnog arbitražnog postupka za svaku od tužbi, vodeći računa o raspoloživim resursima. ${ }^{57}$ Tome treba dodati kvalifikaciju „istovremeno“. Jer sam broj tužbenih zahteva i broj arbitara ne mora biti presudan ukoliko se postupci vode tokom dužeg vremena. Na primer, u mešovitim arbitražnim tribunalima posle Prvog svetskog rata odlučivao je ograničen broj arbitara i postupci su vođeni na manje-više klasičan način, ali su bili vremenski raspoređeni na period koji je trajao više od decenije. Slično se može reći i za arbitražne postupke pred Arbitražnim sudom za iransko-američke zahteve. Hiljade i desetine hiljada predmeta koji su rešeni ovim arbitražama ne bi se mogli rešiti istovremeno jer nije postojao dovoljan broj arbitara niti dovoljno sredstava za simultano sprovođenje tolikog broja individualnih arbitraža. Da su svi ovi sporovi pokrenuti istovremeno, morali bismo ih svrstati u kategoriju kolektivne arbitraže.

52 Hanotiau, B., 2006, Complex Arbitrations - Multiparty, Multicontract, Multi-Issue and Class Actions, Kluwer Law International, p. 262.

53 Giovanni Alemanni and Others v. The Argentine Republic, pasus 267.

54 Martinez, J., 2014, p. 1.

55 To su predmeti Abaclat and others v. Argentine Republic, Ambiente Ufficio S.p.A. and others v. Argentine Republic i Giovanni Alemanni and Others v. The Argentine Republic.

56 Heiskanen, V.A., 2015, p. 614.

57 Kabra, R., 2015, p. 428. 
Pred ICSID-om su se i pre Abaclata vodili sporovi sa više tužilaca. Na primer, u predmetu Funnekotter v. Zimbabve ${ }^{58}$, tužilo je trinaest holandskih ulagača. Međutim, tužena država nije podnela prigovor da kolektivna tužba nije dopuštena, niti je ovo pitanje bilo predmet rasprave. Tek kada se u Abaclatu broj popeo na stotine hiljada, u prvi plan je istaknuto pitanje dopuštenosti kolektivne tužbe.

Abi-Saab, egipatski arbitar koji je u Abaclatu napisao odvojeno mišljenje, slikovito je opisao ovu transformaciju:

„171. Prosta razlika u obimu i broju tužbenih zahteva i tužilaca između bilateralne ili čak i ograničene višestranačke arbitraže (u najvećem takvom slučaju pred ICSID-om bilo je četrnaest tužilaca), koje dozvoljavaju pojedinačno, detaljno i adversarijalno ispitivanje svakog zahteva i tužioca, s jedne strane i 60.000 tužilaca u ovom predmetu, s druge strane, zapanjujuća je. Ona predstavlja pojavu koja se u fizici naziva "kvalitativni skok“ (saut qualitatif), koja posle izvesne tačke transformiše kvantitativnu u kvalitativnu promenu. Ovde je promena u tome što se mikroanaliza i rešavanje pojedinačnih fenomena ( $\mathrm{tj}$. tužbenih zahteva i tužilaca) na pojedinačan način menja i transformiše u makroanalizu i rešavanje velike mase pojedinačnih fenomena kao da je reč o bezličnoj celini, pri kojoj se ne mogu uzimati u obzir individualne karakteristike komponenata." ${ }^{\text {" }}$

Žorž Abi-Sabb opisuje kolektivnu arbitražu kao ne samo kvantitativni već i kvalitativni skok, kao kvalitativnu promenu. Kakav je značaj ove vrste arbitraže za potrošačke sporove? To je pitanje na koje ćemo pokušati da odgovorimo u daljem toku ovog rada. Da li se iskustva stečena u investicionoj arbitraži mogu preneti u oblast potrošačkih sporova?

\section{KARAKTERISTIKE POTROŠAČKIH SPOROVA}

Potrošački sporovi imaju određene opšte karakteristike koje ih razlikuju od ostalih sporova: ${ }^{60}$

- tužilac je, po pravilu, fizičko lice, a tuženi je privredno društvo;

- postoji značajna nejednakost između stranaka u mogućnostima da finansiraju vođenje parnice; ${ }^{61}$

- po pravilu, vrednost spora je mala;

- predmet spora je često naknada štete iz ugovora ili delikta;

- predmet spora je često identičan ili vrlo sličan sa predmetom drugih sporova između drugih tužilaca i istog tuženog;

58 ICSID, Bernardus Henricus Funnekotter and others v. Republic of Zimbabwe, Case No. $\mathrm{ARB} / 05 / 6$.

59 ICSID, Abaclat and others v. Argentine Republic, Case No. ARB/07/05, Dissenting opinion Georges Abi-Saab, 4 August 2011. (napomene su izostavljene iz citata).

60 Stanivuković, M., Arbitration: Is it a viable option for resolution of consumer disputes in Serbia?, in: Taboroši, S., Bourgoignie, T., Jovanić, T. (eds.), 2013, Strengthening Consumer Protection in Serbia, Pravni fakultet Univerziteta u Beogradu, p. 230.

61 Misli se na kapacitet stranke da finansira vođenje parnice angažovanjem advokata i veštaka i plaćanjem sudske takse. 
- pravni odnos između stranaka regulišu, pored obligacionog prava, imperativne zakonske norme o zaštiti potrošača kojima se štiti javni interes.

Često je broj istovrsnih potrošačkih transakcija i sporova koji mogu iz njih proisteći veliki. Zbog toga se smatra da je reč o sporovima male vrednosti i visoke frekventnosti (small value, high volume disputes). ${ }^{62}$

Sve ove karakteristike ne moraju biti prisutne u svakom pojedinačnom potrošačkom sporu, ${ }^{63}$ ali je značajno izdvojiti ih na teorijskom planu da bi se lakše prepoznala priroda spora u praksi.

Potrošački spor sa inostranim elementom dodatno odlikuju sledeće karakteristike: $^{64}$

- stranke imaju redovno boravište u različitim zemljama, često vrlo udaljenim;

- stranke govore različite jezike;

- stranke posluju u okviru različitih pravnih sistema i na njih se primenjuju različiti imperativni propisi.

Imajući u vidu navedene karakteristike, opravdano je postaviti pitanje da li je arbitraža uopšte pogodan mehanizam za rešavanje potrošačkih sporova, uključujući i kolektivne potrošačke sporove. Naime, arbitraža u svom modernom obliku služi za rešavanje sporova između ravnopravnih stranaka, kao što su države i privredna društva. Nije sigurno da ona može uspešno da posluži za rešavanje sporova između nejednakih subjekata kao što su trgovac i potrošač.

Rešavanje sporova ove vrste predstavlja problem zbog toga što su troškovi svakog mehanizma rešavanja sporova, bio to sud ili arbitri, nesrazmerno veliki u odnosu na vrednost pojedinačnog potrošačkog spora koja može biti veoma mala. Usled male vrednosti, potrošaču se ne isplati da pokreće spor, naročito spor sa inostranim elementom. Troškovi plaćanja eventualne sudske takse, aktorske kaucije i angažovanja advokata daleko bi prevazišli iznos koji se može ostvariti vođenjem parnice. Ova „neisplativost“ rešavanja potrošačkih sporova posebno je izražena u arbitraži koja nudi bržu i kvalitetniju, ali i skuplju uslugu od državnog pravosuđa. Američka sudska praksa je zauzela stav da visina arbitražnih troškova može da dovede do rušljivosti arbitražnog sporazuma u potrošačkom ugovoru. Teret dokazivanja da su troškovi prohibitivni je na potrošaču. ${ }^{65}$ Engleski zakon o arbitraži predviđa da se arbitražni sporazum smatra nepoštenim

62 Rule, C., Rogers, V., Del Duca, L. F., 2010, Designing a Global Consumer Online Dispute Resolution (ODR) System for Cross-Border Small Value - High Volume Claims - OAS Developments, Uniform Commercial Code Law Journal, Vol. 42, p. 221, (https://papers.ssrn.com/ sol3/papers.cfm?abstract_id=1635463).

63 Na primer, vrednost spora zbog kupovine skupe bele tehnike ili skupog nameštaja može biti velika, ali se i dalje radi o potrošačkom sporu ako su stvari kupljene za ličnu ili porodičnu upotrebu.

64 Stanivuković, M., 2013, p. 230.

65 Bates, D. M., 2003, A Consumer's Dream or Pandora’s Box: Is Arbitration a Viable Option for Cross-Border Consumer Disputes?, Fordham International Law Journal, Vol. 27, Issue 2, p. 860 . 
ukoliko je predmet tužbe skroman iznos. ${ }^{66}$ Poznate arbitražne institucije, kao što je Međunarodni arbitražni sud MTK, ne pružaju usluge potrošačke arbitraže, jer potrošač ne bi mogao da ih priušti.

Drugi razlog zbog kojih se sumnja da je arbitraža pogodan mehanizam za rešavanje potrošačkih sporova nalazi se u činjenici da je arbitraža privatan način rešavanja sporova, a potrošački sporovi pokreću pitanja od javnog interesa. Da li se arbitrima može verovati da će na odgovarajući način da zaštite javni interes, da će dosledno primeniti imperativne odredbe merodavnog prava kojima se štite prava potrošača kao slabije strane u ugovornom odnosu?

Treći razlog odnosi se na saglasnost volja. Osnov arbitraže je arbitražni sporazum. Spor može da se rešava putem arbitraže samo na osnovu sporazuma. ${ }^{67}$ Zaključenjem arbitražnog sporazuma stranke se odriču sudske zaštite. Pretpostavka je da su stranke dobrovoljno pristale na arbitražu, ali potrošački ugovori se većinom zaključuju po pristupu, kao adhezioni ugovori, tako da ta pretpostavka ne mora uvek biti tačna. Neophodno je utvrditi da se potrošač svesno i voljno odrekao svog osnovnog prava na sudsku zaštitu. ${ }^{68}$

Iz ovoga proističu različita ograničenja arbitrabilnosti potrošačkih sporova u uporednom pravu. ${ }^{69}$ Ona se mogu javiti u obliku odredaba kojima se priznaje punovažnost samo arbitražnim sporazumima zaključenim posle nastanka spo$\mathrm{ra}^{70}$ ili u obliku odredaba kojima se zahteva posebna forma arbitražnog sporazuma koja svojim zahtevima obezbeđuje da potrošač promišljeno pristane na arbitražu. ${ }^{71}$

U mnogim zemljama, naročito u članicama EU, automatski se smatra da je klauzula o ugovaranju arbitraže nepoštena odredba u potrošačkom ugovoru ako

66 Engleski zakon o arbitraži (1996), paragraf 91. Uredbom je skroman iznos trenutno određen na 5000 funti.

67 Zakon o arbitraži, Sl. glasnik RS, br. 46/06, član 4.

68 Stanivuković, M., 2013, p. 234.

69 Podaci o uporednom zakonodavstvu o arbitraži mogu se naći u publikaciji Bosman, L. (ed.), ICCA International Handbook on Commercial Arbitration, Kluwer Arbitration, (http://www. kluwerarbitration.com/, 30. 7. 2020).

70 U Norveškoj, paragraf 11 Zakona o arbitraži predviđa da arbitražna klauzula u potrošačkom ugovoru kojom se predviđa arbitraža za buduće sporove nije punovažna. Arbitraža se može ugovoriti samo za već nastale sporove iz potrošačkog ugovora. Isto pravilo važi i u pravu Švedske na osnovu paragrafa 6. Zakona o arbitraži, u pravu Danske, prema paragrafu 7(2) Zakona o arbitraži iz 2005. godine i u pravu Litvanije na osnovu člana 12. Zakona o trgovinskoj arbitraži. U Kvebeku, sporovi iz potrošačkih ugovora nisu arbitrabilni, izuzev ako se stranke sporazumeju o arbitraži posle izbijanja spora (ovo je predviđeno u Paragrafu 11.1. Zakona o zaštiti potrošača). U ostalim kanadskim provincijama, arbitrabilnost potrošačkih ugovora takođe može biti dovedena u pitanje s pozivom na odluku Vrhovnog suda Kanade iz 2011. godine u predmetu Seidel v. Telus Communications Inc. Supreme Court of Canada, Seidel v. TELUS Communications Inc., Case no. 33154, Judgment of March 18, 2011.

71 U Nemačkoj, arbitražni sporazum sa potrošačem mora da bude zaključen kao poseban dokument koji su potpisale obe stranke i koji se odnosi samo na arbitražu. Alternativno, sporazum može biti sadržan i u potrošačkom ugovoru koji je overen kod beležnika. ZPO, paragraf 1031(5). Isto pravilo primenjuje se i u Hrvatskoj. Uzelac, A., National Report for Croatia, in: Bosman, L. (ed.), 2020, ICCA International Handbook on Commercial Arbitration, ICCA \& Kluwer Law International, Supplement No. 109, p. 16. 
se o njoj nije posebno pregovaralo. ${ }^{72}$ Stav da su arbitražne klauzule sumnjive važnosti zauzet je već u Direktivi o nepoštenim ugovornim odredbama iz $1993,{ }^{73}$ a u međuvremenu je implementiran u zakonodavstvu država članica. U novije vreme, pojedine zemlje, poučene negativnim iskustvima u praksi, odlučuju da potpuno isključe arbitrabilnost potrošačkih sporova. ${ }^{74}$ Indikativno je i to da su poznate američke arbitražne institucije odlučile i objavile da neće da se bave potrošačkim sporovima i potrošačkim klasnim tužbama. ${ }^{75}$

Na kraju treba pomenuti i zabrinutost da bi u potrošačkim sporovima mogla biti dovedena u pitanje nepristrasnost i nezavisnost arbitara. Bojazan je da bi arbitri, pa i arbitražne institucije, mogli biti naklonjeniji jačoj strani u potrošačkom odnosu jer su korporacije te koje će najpre uvrstiti arbitražnu klauzulu u potrošački ugovor i koje će se češće javljati kao stranka (repeat players), dok će pojedinačni potrošač u toj ulozi da se pojavi sporadično. ${ }^{76} \mathrm{U}$ kolektivnim potrošačkim sporovima, međutim, situacija se može obrnuti i isto pitanje nepristrasnosti i nezavisnosti arbitra može se postaviti u odnosu na advokate tužilačke strane, koji su inicijatori kolektivnih sporova iz kojih mogu proisteći posao i veliki honorar za arbitra.

\section{RAZLOZI KOJI GOVORE U PRILOG I PROTIV KOLEKTIVNE ARBITRAŽE U POTROŠAČKIM SPOROVIMA}

Kao glavni razlozi za kumulaciju više zahteva u istom postupku navode se uštede u vremenu i troškovima, efikasnost, ujednačenost ishoda i, na kraju, bolji pristup pravdi. ${ }^{77}$

72 Npr. prema poljskom Građanskom zakoniku, član 3851, paragraf 1 i član 3853, tačka 23. U Irskoj, Zakon o arbitraži iz 2010. godine određuje (paragraf 30) da arbitražni sporazum sa potrošačem ukoliko se o sporazumu nije posebno pregovaralo i ako spor ne premašuje iznos od 5000 evra, ne vezuje potrošača.

73 The Council of the European Communities, Council Directive 93/13/EEC of 5 April 1993 on unfair terms in consumer contracts, Annex, Section 1, Item q, Official Journal of the European Communities, L 95/29, 21 April 1993.

74 Prema češkom Zakonu o arbitraži sa izmenama od 1. decembra 2016. godine, ne može se voditi arbitraža u sporovima u kojima je jedna od stranaka potrošač. Olík, M., National Report for the Czech Republic, in: Bosman, L. (ed.), 2020, ICCA International Handbook on Commercial Arbitration, ICCA \& Kluwer Law International, Supplement No. 109, p. 2. Dakle, u Češkoj, potrošački sporovi nisu arbitrabilni. Ovaj podatak je zanimljiv, s obzirom na činjenicu da je pre izmena zakona, oko 150.000 arbitražnih odluka u Češkoj bilo potpisivano u oblasti potrošačkih sporova. Bélohlávek, A. J., Class Actions \& Arbitration Procedures Czech Republic, in: Billiet, P., Hensler, D., Tzankova, I. (eds.), 2013, Class Actions \& Arbitration in the European Union, Maklu, p. 64. Slično je i u Bugarskoj, posle izmena Zakona o međunarodnoj trgovinskoj arbitraži iz 2017. godine. Alexiev, A., National Report for Bulgaria, in: Bosman, L. (ed.), 2019, ICCA International Handbook on Commercial Arbitration, ICCA \& Kluwer Law International, Supplement No. 104, p. 13.

75 Prvo je 2009. National Arbitration Forum prestao da prihvata nove potrošačke arbitraže. Zatim je 2010. i Američko udruženje za arbitražu objavilo izjavu da neće nadalje prihvatati tužbe koje se odnose na naplatu potrošačkih dugova.

76 Bates, D. M., 2003, p. 855.

77 Radicati di Brozolo, L. G., Ponzano, F., 2016, p. 129. Kabra, R., 2015, p. 431. 
Već je pomenuta neisplativost vođenja potrošačkog spora, s obzirom na visoke troškove arbitraže. Upravo ova karakteristika arbitraže bledi ili otpada u kontekstu masovnih potrošačkih zahteva. Zahvaljujući činjenici da se arbitražni troškovi u kolektivnoj arbitraži raspodeljuju na veliki broj stranaka, arbitražni postupak postaje dostupniji i isplativiji. Kada se kumuliraju, tj. zbirno postave zahtevi male vrednosti, vrednost spora postaje dovoljno velika da bi mogao da se finansira rad arbitra. Takođe, lakše se dolazi do trećeg lica kao finansijera. Pretpostavka za efikasno odlučivanje je da su tužbeni zahtevi dovoljno slični da bi omogućili paušalno odlučivanje i da ne zahtevaju zaseban tretman. ${ }^{78}$

Ušteda u troškovima ostvaruje se po nekima i za tuženog, jer se tuženom omogućava da koncentriše pravni i činjenični osnov svoje odbrane. Takođe, obezbeđuje se da arbitražni sud bude upoznat sa činjeničnim stanjem bez potrebe da ga u svakom novom predmetu advokati iznova "podučavaju“ o relevantnim činjenicama. ${ }^{79}$

S druge strane, kolektivna arbitraža predstavlja značajan teret za tuženog. Ona obično nije u njegovom interesu, a može i da mu uskrati ili ograniči određena procesna prava. ${ }^{80}$

U stvari, procesna prava obeju strana mogu biti ograničena u kolektivnom postupku. Arbitražni sud u predmetu Abaclat objašnjava: ako je spor pokrenulo na desetine hiljada tužilaca, nemoguće je ispitati svakog od njih pojedinačno. Neizbežno je, kako kaže arbitražni sud, da se vrše određena uopštavanja i/ili grupno ispitivanje. ${ }^{81}$ Takođe, tuženi će morati da iznese odbranu polazeći od navoda iz kolektivne tužbe, bez mogućnosti da pojedinačno argumentuje okolnosti koje se odnose na svakog pojedinačnog tužioca. ${ }^{82}$

Ravnopravnost stranaka i načelo kontradiktornosti, tj. pravo svake stranke da bude saslušana, predstavljaju bitna načela arbitražnog postupka ${ }^{83}$ Narušavanje ovih načela predstavlja razlog za poništaj arbitražne odluke. Pitanje je da li su kolektivne tužbe u skladu sa načelom kontradiktornosti, jer tuženi nije u prilici da se izjasni o dokazima i stavovima svakog pojedinačnog tužioca.

U ugovoru između tužilaca i organizacije Task Force Argentina (dalje: TFA), koja je inicirala pokretanje arbitraže u predmetu Abaclat, bilo je navedeno da se tužioci odriču određenih procesnih prava. Arbitri su morali da odluče da li je odricanje punovažno. Zauzeli su stav da su se usvajanjem ugovora sa TFA, tužioci punovažno odrekli prava na odlučivanje o vođenju postupka, prava na angažovanje sopstvenog advokata i slično. Arbitri su istakli da nije reč o potrošačkom sporu, mada mnogi od tužilaca imaju profil sličan potrošačima. Reč je o sporu koji se odnosi na raznolike finansijske investicije. Zbog toga, priroda i stepen obaveštenosti nisu morali da budu isti kao u kontekstu isklju-

78 Ibid., p. 428.

79 Heiskanen, V. A., 2015, p. 524.

80 Kabra, R., 2015, p. 434.

81 Abaclat and others v. Argentine Republic, pasus 296.

82 Ibid., pasus 536. Kao pitanje koje će se razmatrati kolektivno, arbitražni sud je naveo postojanje eksproprijacije.

83 Zakon o arbitraži, Sl. glasnik RS, br. 46/06, član 33. 
čivo potrošačkih transakcija. TFA je imao pravo da očekuje da ulagači imaju određeni nivo znanja. ${ }^{84}$

Takođe, ocenili su da je ograničenje prava Argentine na odbranu relativno. Istina je da Argentina neće moći da se upozna sa punim detaljima pojedinačnih okolnosti svakog od tužilaca, ali nije sigurno da bi takvo upoznavanje uopšte bilo neophodno, s obzirom na homogenost zahteva tužilaca. Uostalom, jedina alternativa bi bilo vođenje šezdeset hiljada zasebnih postupaka. ${ }^{85}$

Ističe se da tužioci u kolektivnoj arbitraži imaju manje uticaja na vođenje postupka i ne mogu da se ponašaju samostalno kako bi to mogli u individualnoj arbitraži ${ }^{86}$ Uloga pojedinačnih tužilaca je mnogo pasivnija i suštinski je preneta na onoga ko ih je organizovao i ko za njih vodi spor i donosi odluke. Po ovoj karakteristici se kolektivna arbitraža približava klasnoj arbitraži, jer je većina tužilaca samo formalno pokrenula spor a, u stvari, ne učestvuje aktivno u njemu. U predmetu Abaclat, arbitri su konstatovali da: „ovaj postupak liči na neku hibridnu vrstu kolektivnog postupka, u smislu da počinje kao zbirni postupak, ali se zatim nastavlja sa karakteristikama koje su slične zastupničkom postupku zbog velikog broja učesnika na strani tužioca. ${ }^{\text {" } 77}$

Ujednačenost ishoda pozitivno utiče na legitimnost sistema arbitražnog rešavanja sporova. Objedinjavanjem postupka sprečava se da različiti arbitražni sudovi dođu do različitih zaključaka na osnovu suštinski istih činjenica i istog prava. ${ }^{88}$ Takođe, postojanje kolektivne arbitraže može povoljno uticati na spremnost privrednika da ispuni zahteve oštećenih potrošača ili da im ponudi poravnanje. Jer, moć udruženih tužilaca izjednačava se sa moći tužene korporacije.

Značajno je, iz ugla potrošačkih sporova, da je u predmetu Abaclat, po nekim mišljenjima, bilo stavljeno na probu načelo pristupa pravdi, jer su vlasnici argentinskih obveznica pojedinačno potraživali toliko skromne iznose da većina njih ne bi bila u stanju da samostalno vodi investicionu arbitražu. ${ }^{89}$ Arbitražni sud je svojom većinskom odlukom o nadležnosti i dopuštenosti tužbe obezbedio pobedu tog načela.

Razmatrajući dopuštenost tužbe, većina u arbitražnom veću u predmetu Abaclat ustanovila je da je zajednička crta za sve kolektivne postupke da su se oni pojavili onda kada su predstavljali jedini način da se obezbedi efikasno pravno sredstvo za zaštitu subjektivnih prava ustanovljenih ugovorom ili zakonom. Drugim rečima, kolektivni postupak se nametao kao neophodan onda kada bi odsustvo takvog postupka imalo za posledicu da se tužioci de fakto lišavaju subjektivnih prava usled nepostojanja odgovarajućeg postupka za njihovu zaštitu. ${ }^{90}$ Kolektivni postupak je omogućavao finansijski slabim strankama pristup kvali-

84 Abaclat and others v. Argentine Republic, pasus 461.

85 Ibid., pasus 545.

86 Radicati di Brozolo, L. G., Ponzano, F., 2016, p. 136.

87 Abaclat and others v. Argentine Republic, pasusi 487-488.

88 Heiskanen, V. A., 2015, p. 624.

89 Radicati di Brozolo, L. G., Ponzano, F., 2016, p. 129.

90 Abaclat and others v. Argentine Republic, pasus 484. 
tetnom i efikasnom načinu rešavanja sporova. ${ }^{91}$ Tako je i u predmetu Abaclat, ICSID arbitraža bila dostupna ulagačima sa relativno malim tužbenim zahtevima samo ukoliko bi se dozvolilo da svi istovremeno podnesu tužbe.

Pored ograničavanja procesnih prava stranaka, kao razlozi protiv kolektivne arbitraže mogu se navesti: nedostatak zakonskog i institucionalnog okvira, nekompatibilnost sa osnovnim načelima arbitraže i mogućnost zloupotreba.

Tradicionalna arbitraža je zasnovana na konceptu individualnog, a ne kolektivnog ostvarivanja prava, i u osnovi je dvostranačka (bilateralna, binarna), a višestranačke arbitraže predstavljaju nov i još nedovoljno razrađen koncept. Većina zakona o arbitraži, ${ }^{92}$ uključujući i naš Zakon o arbitraži, ne sadrži posebna pravila o višestranačkoj arbitraži. Ako ih i sadrže, to su uglavnom odredbe o imenovanju tročlanog arbitražnog veća u slučaju višestranačke arbitraže..$^{93}$ Arbitražne institucije se mogu podeliti u tri kategorije. Jedan broj institucija izričito dozvoljava kolektivne arbitraže,${ }^{94}$ druge ih izričito zabranjuju, a treće u svom pravilniku nisu predvidele izričitu odredbu o tome. Većina institucija spada u treću kategoriju ${ }^{95}$ One institucije koje dozvoljavaju kolektivne arbitraže, uglavnom u pravilnicima propisuju samo odredbe o imenovanju arbitara. Pravila DIS-a sadrže nešto detaljnije odredbe o višestranačkoj arbitraži i o arbitraži koja proističe iz više ugovora u čl. 17. i 18. Na posebna pravila o kolektivnoj arbitraži retko se nailazi, osim u američkom pravu. U svakom slučaju, nedostatak pravila o kolektivnoj arbitraži ne mora da spreči podnošenje kolektivne tužbe, kao što nam pokazuje američko iskustvo i investiciona arbitraža. Kao primer da neka posebna pravila o kolektivnoj arbitraži nisu neophodna navodi se i predmet $A n$ dersen protiv Andersena koji se pojavio kasnih devedesetih godina pred arbitražnim sudom MTK. U sporu koji se vodio po standardnom pravilniku MTK o međunarodnoj trgovinskoj arbitraži učestvovala je 141 stranka, 44 na strani tužioca i 97 na strani tuženog. ${ }^{96}$

Arbitražni sporazum i arbitražna odluka imaju naglašeno inter partes dejstvo. Arbitražni sporazum obavezuje strane koje su ga prihvatile. U načelu, dej-

91 Kabra, R., 2015, p. 431.

92 Korišćeni su uporednopravni podaci iz publikacije Bosman, L. (ed.), ICCA International Handbook on Commercial Arbitration, Kluwer Arbitration, (http://www.kluwerarbitration. $\mathrm{com} /$, 30. 7. 2020).

93 Odredbe o imenovanju arbitara u višestranačkoj arbitraži sadrže na primer: francuski Zakon o građanskom postupku, četvrta knjiga o arbitraži, izmenjen Uredbom br. 2011-48 od 13. januara 2011, u članu 1453; poljski Zakon o građanskom postupku, peti deo, izmenjen Zakonom od 28. jula 2005. u članu 1169, paragraf 2(1); Zakon o trgovačkoj arbitraži Litvanije (2012), u članu 14(5)-(6); italijanski Zakon o građanskom postupku, četvrta knjiga, naslov VIII, izmenjen i dopunjen Zakonskom uredbom br. 40 od 2. februara 2006, u članu 816-quarter.

94 Na primer, Švajcarska pravila sadrže odredbe o imenovanju arbitara u višestranačkoj arbitraži u članu 8(3)-8(5); Arbitražna pravila UNCITRAL-a, u članu 10, stav 1 i Arbitražna pravila MTK, u članu 12, stav 6.

95 Strong, S. I., 2013, p. 34.

96 Strong, S. I., 2019, p. 30. Kabra, R., 2015, p. 431. Vid. Ostrager, B. R., Thomas, P. C., Smit, R. H., 1999, Andersen v. Andersen: The Claimant's Perspective, The American Review of International Arbitration, Vol. 10, No. 4, p. 443. 
stvo arbitražnog sporazuma ne može se proširiti na lica koja nisu vezana arbitražnim sporazumom. Lica koja nisu vezana arbitražnim sporazumom ne mogu, $\mathrm{s}$ jedne strane, biti pozvana da učestvuju kao stranke u arbitražnom postupku protivno svojoj volji i ne mogu, s druge strane, zahtevati da učestvuju u arbitražnom postupku kao umešači ili kao stranke protivno volji stranaka između kojih je spor pokrenut. Arbitražna odluka vezuje samo subjekte koji su bili stranke u arbitražnom sporu i, eventualno, njihove pravne sledbenike.

Iz inter partes dejstva arbitraže proističe zaključak da je višestranačka arbitraža moguća samo ako su sve stranke vezane istim arbitražnim sporazumom. Međutim, pod istim arbitražnim sporazumom podrazumeva se i više arbitražnih sporazuma koji su međusobno kompatibilni. ${ }^{97}$ Arbitražne klauzule sadržane u investicionim sporazumima (BIT-ovima) jesu primer za to.

U investicionoj arbitraži Guaracachi America, Inc. \& Rurelec plc v. Bolivia, dva privredna društva, jedno američko, a drugo iz Ujedinjenog Kraljevstva, pokrenula su arbitražu protiv Bolivije navodeći zasebne arbitražne sporazume sadržane u američko-bolivijskom i britansko-bolivijskom BIT-u. Arbitražni sud je većinskom odlukom odbio prigovor nenadležnosti jer nije potreban poseban pristanak tuženog da bi tužioci mogli da pokrenu jednu jedinstvenu arbitražu na osnovu različitih BIT-ova. Ponuda u BIT-ovima da se investicioni sporovi reše arbitražom nije bila uslovljena bilo kakvim ograničenjem te vrste. ${ }^{98}$

Jedno od temeljnih načela arbitraže je pravo stranaka da utiču na izbor arbitara. Ovo pravo se međutim, ne može u potpunosti ostvariti u višestranačkim postupcima, a još manje u kolektivnoj arbitraži. Razlog za to je u činjenici da množina tužilaca ima pravo da imenuje samo jednog arbitra. Ako bi se predstavniku tužilaca, ili njegovom advokatu, dalo pravo da imenuje arbitra u ime svih članova grupe, ostali članovi grupe bili bi vezani odlukom arbitra na čiji izbor nisu imali nikakvog uticaja. ${ }^{99}$ Ukoliko se ne može postići sporazum o imenovanju, rešenje se, po pravilu, nalazi u većim ovlašćenjima institucije. ${ }^{100}$

Ukoliko stranke nisu vezane istim arbitražnim sporazumom, ovlašćenja institucije da imenuje arbitra mogu biti pod znakom pitanja. U jednoj arbitraži, koja je proistekla iz ulaganja u solarni sektor, ulagači, njih deset, pokrenuli su protiv Češke Republike prvo jedan zajednički arbitražni spor na osnovu ECT-a i dvostranih sporazuma sa Holandijom, Nemačkom, Kiprom, Luksemburgom i Ujedinjenim Kraljevstvom. Tužioci nisu bili međusobno povezani, ali se tužbeni zahtev odnosio na iste propise o foto-naponskom sektoru i zastupala ih je ista

97 Poudret, J. F., Besson, S., Berti, S. V., Fonti, A., 2007, Comparative law of international arbitration, Thomson Sweet \& Maxwell, $2^{\text {nd }}$ edition, p. 201. Vid. takođe, arbitražna pravila MTK, član 6, stav 4, Arbitražna pravila UNCITRAL-a, član 17, stav 5, Arbitražna pravila DIS-a, član 17 itd.

98 UNCITRAL, Guaracachi America, Inc. and Rurelec PLC v. The Plurinational State of Bolivia, PCA Case No. 2011-17, Award, 31 January 2014, pasusi 334-346.

99 Janićijević, D., 2006, str. 120.

100 Na primer AAA u slučaju da se stranke nisu saglasile o broju arbitara, imenuje arbitra pojedinca, osim ako ne odluči, po slobodnoj oceni, da je potrebno imenovati tri arbitra. Bar jedan od arbitara u klasnoj arbitraži mora biti imenovan sa nacionalne liste specijalista za klasnu arbitražu koju vodi AAA. Videti Supplementary Rules for Class Arbitrations, član 2. 
advokatska kancelarija. Češka je na kolektivnu tužbu odgovorila tako što je imenovala različite arbitre za svaki tužbeni zahtev, zastupajući tezu da mora da se obrazuje šest posebnih arbitražnih veća. Četiri od tih veća su ipak imenovana u identičnom sastavu (Češka je imenovala istog arbitra, ali je postavila uslov da tužioci ne mogu da traže spajanje postupaka). Tužilac se zatim obratio Stalnom arbitražnom sudu, organu imenovanja na osnovu arbitražnih pravila UNCITRAL-a, sa zahtevom da imenuje arbitra umesto Češke Republike, jer je tužena odbila da imenuje samo jednog arbitra za sve sporove. Stalni arbitražni sud je zahtev odbio i formirana su posebna veća za svaki od sporova. ${ }^{101}$

Kada se sa jedne strane stave problemi inherentni potrošačkim sporovima koji otežavaju spoj između potrošačkih sporova i arbitraže, a sa druge strane razlozi koji govore protiv kolektivne arbitraže, u zbiru se dobija trenutno većinski negativan stav u Evropi u odnosu na kolektivnu arbitražu u potrošačkim sporovima. Međutim, jasno je da se mora iznaći pogodno rešenje za problem masovnih šteta. Evropska unija je krajem 2018. godine usvojila predlog Direktive o zastupničkim tužbama za zaštitu kolektivnih interesa potrošača. ${ }^{102}$ Predlog ne predviđa kolektivnu arbitražu nego kolektivni postupak pred sudom ili pred organom uprave (po izboru države članice), s tim da je u okvirima takvih postupaka moguće koristiti druge vansudske načine rešavanja sporova (ADR) radi postizanja poravnanja. Među te druge načine rešavanja sporova svrstava se i arbitraža. ${ }^{103}$

Poseban problem vezan za kolektivnu arbitražu, o kome svakako treba voditi računa, jeste rizik od zloupotreba. Izveštač Evropskog parlamenta o predloženoj direktivi o kolektivnoj zaštiti u svom izveštaju, između ostalog, predlaže da se moraju precizno odrediti kriterijumi za kvalifikovane predstavnike tužilaca. Oni ne smeju zaključivati bilo kakve finansijske sporazume sa advokatskim društvima koja zastupaju tužioce, osim uobičajenih ugovora o angažovanju. Takođe, moraju objavljivati podatke o svom načinu finansiranja, organizaciji i organima upravljanja. ${ }^{104}$ Čini se da često advokatska društva koriste kolektivne tužbe za ostvarivanje nesrazmerne zarade, ${ }^{105}$ a ponekad su i ostvarene naknade štete pre-

101 Vid. Radicati di Brozolo, L. G., Ponzano, F., 2016, p. 134. Čini se da su kasnije ta četiri spora ipak spojena u jedan. Vid. Ross, A., 2018, Czech Republic hits back at reports of solar loss, Global Arbitration Review, p. 2, (https://globalarbitrationreview.com/article/1153107/czechrepublic-hits-back-at-reports-of-solar-loss).

102 Proposal for a Directive of the European Parliament and of the Council on representative actions for the protection of the collective interests of consumers, and repealing Directive 2009/22/EC, Brussels, 11. 4. 2018, (https://ec.europa.eu/info/sites/info/files/proposal_for_a_directive_on_ representative_actions_for_the_protection_of_the_collective_interests_of_consumers_0.pdf).

103 British Institute of International and Comparative Law, ADR and Collective Redress, (https:// www.collectiveredress.org/collective-redress/alternative-adr, 28. 7. 2020).

104 Videti izveštaj na sajtu Evropskog parlamenta, o napredovanju zakonodavne procedure. https://www.europarl.europa.eu/legislative-train/theme-area-of-justice-and-fundamentalrights/file-representative-actions-for-consumers. Takođe, informativan je i Green Paper Evropske komisije o kolektivnoj zaštiti potrošača koji je objavljen još 2008: Green Paper On Consumer Collective Redress /* COM/2008/0794 final (/ https://eur-lex.europa.eu/legal-content/en/TXT/?uri=CELEX\%3A52008DC0794).

105 Mogućnost za to proističe iz režima naplate advokatskih troškova koji se naziva contingency fee - advokati imaju pravo da naplate procenat od dobijenog iznosa u slučaju uspeha u sporu. 
terane i nerazumne. ${ }^{106} \mathrm{U}$ vezi sa američkim klasnim tužbama pominje se čak i sudska ucena tuženih korporacija jer su troškovi ovakvih postupaka toliko visoki da teško opterećuju budžete korporacija. ${ }^{107}$

Jedan primer širokog dijapazona zloupotreba koje su moguće u klasnim tužbama daje nam slučaj Frank v. Gaos pred Vrhovnim sudom SAD. Prvobitno, tužbu su protiv korporacije Google podneli korisnici pretraživača na osnovu povrede privatnosti - jer je Google trećim licima, prodajnim veb-sajtovima, ustupao termine za pretragu koje su tužioci koristili u svom veb-brauzeru. Kalifornijski sud je prihvatio klasnu tužbu i objavio obaveštenje da su tužilačkom klasom obuhvaćeni svi korisnici na teritoriji SAD koji su od 25. oktobra 2006. do datuma obaveštenja koristili Google pretragu, što je u tom trenutku obuhvatalo oko 129 miliona ljudi. Usledila je medijacija, a ubrzo i poravnanje prema kome je trebalo da korporacija Google plati 8,5 miliona dolara u fond za poravnanje iz koga su zatim naplaćeni administrativni troškovi, nagrade predstavnicima klase (po pet hiljada dolara) i advokatski troškovi, koji su izneli dva miliona dolara. U poravnanju je bilo predviđeno da će se ostatak od 5,3 miliona dolara direktno podeliti u korist šest organizacija koje će se baviti projektima posvećenim privatnosti na internetu. ${ }^{108}$ Nije bilo dogovoreno da će pojedinačni pripadnici klase dobiti bilo kakvu naknadu za štetu koju su pretrpeli. Takođe, Google se nije obavezao da će izvršiti bilo kakve promene svog Google Search portala.

Dva pojedinca, pripadnika klase, podnela su primedbe. Oni nisu bili zadovoljni poravnanjem, koje bi, kada bi se dosuđena suma isplatila svim tužiocima, iznosilo samo 4 centa po tužiocu. Štaviše, istakli su da je preostali iznos od 5,3 miliona dolara podeljen univerzitetima na kojima su studirali advokati tužilaca i organizacijama čiji je sponzor odranije bio Google. ${ }^{109}$ Sve to je ukazivalo na dosluh između advokata tužilaca i tuženog Google-a, na štetu tužilaca. Komentatori ukazuju na opasnost da se advokati tužilaca u klasnim tužbama otrgnu kontroli i da sklapaju sporazume koji nisu u korist klijenata. ${ }^{110}$

Na kraju, govoreći o prednostima i nedostacima kolektivne arbitraže u potrošačkim sporovima, treba istaći još jednu stvar. U prekograničnim potrošačkim sporovima često ni sud tužioca, ni sud tuženog nije dovoljno neutralan i nepristrasan forum, jer se, $s$ jedne strane, stvara negativno javno mnjenje zbog ponašanja strane korporacije, a s druge strane nastojanje da se domaća korporacija zaštiti od propasti do koje bi mogli dovesti masovni tužbeni zahtevi za

106 British Institute of International and Comparative Law, ADR and Collective Redress, (https:// www.collectiveredress.org/collective-redress/alternative-adr, 28. 7. 2020).

107 Martinez, J., 2014, p. 2.

108 Ovaj vid raspodele dobijenog iznosa u klasnoj tužbi naziva se cy pres payment što je naziv koji potiče od cy-près doctrine.

109 To su bile sledeće organizacije: Carnegie-Mellon University; World Privacy Forum; Chicago Kent College of Law Center for Information, Society and Policy; Stanford Law School Center for Internet and Society; Berkman Center for Internet \& Society at Harvard University; and AARP.

110 Vrhovni sud SAD još nije doneo odluku u ovom predmetu. 
odštetu. Sve više se zbog toga u oblasti prekograničnih potrošačkih sporova razmišlja o kolektivnoj arbitraži kao mehanizmu koji može da ponudi rešavanje ove vrste sporova, po meri i potrebama stranaka.

\section{DA LI JE KOLEKTIVNA POTROŠAČKA ARBITRAŽA MOGUĆA I DA LI JE POŽELJNA U SRBIJI?}

U ovom delu rada ukratko se razmatra mogućnost korišćenja postojeće strukture - Zakona o arbitraži i pravilnika dveju arbitražnih institucija u Srbiji za organizovanje kolektivne potrošačke arbitraže. Zakon o zaštiti potrošača ima u vidu arbitražu kao način rešavanja sporova. ${ }^{111}$ Članom 144. predviđena je shodna primena odredaba Zakona o arbitraži na postupak vođenja i okončanja vansudskog rešavanja potrošačkog spora. Međutim, ugovorna odredba kojom se potrošaču nameće obaveza da sporove rešava pred arbitražom [sic!] na način koji je u suprotnosti sa odredbama ZZP-a, smatra se nepravičnom ugovornom odredbom. Pokretanje i vođenje arbitražnog postupka ne isključuje pravo potrošača na sudsku zaštitu. ${ }^{112}$

Zakon o arbitraži ne sadrži odredbe o višestranačkoj arbitraži. Međutim, izostanak odredaba ne predstavlja prepreku za pokretanje arbitražnog postupka od strane više tužilaca. Ta situacija je predviđena u Beogradskim pravilima Beogradskog arbitražnog centra (2014) i u Pravilniku Stalne arbitraže (2016). Odredbe koje pravila domaćih institucija sadrže odnose se na način imenovanja arbitara u višestranačkoj arbitraži i na izračunavanje arbitražnih troškova. Beogradska pravila predviđaju u članu 18:

„Ako spor rešava tročlano veće, a u sporu se na tužilačkoj ili na tuženoj strani pojavljuje više lica, ona sporazumno imenuju zajedničkog arbitra. Ako ne izvrše imenovanje u rokovima predviđenim ovim Pravilnikom, Predsednik imenuje celokupni sastav arbitražnog veća, pri čemu može da opozove arbitra koji je već imenovan i da ponovo imenuje arbitra koji je već imenovan u veće, kao i da odredi jednog od njih kao predsedavajućeg."

Član 6. Tarife Beogradskog arbitražnog centra predviđa:

„U sporovima sa množinom procesnih subjekata, iznosi obračunati u skladu sa članovima 2, 3, 4 i 5 ove Tarife uvećavaju se za 10 odsto za svakog dodatnog učesnika u sporu, do maksimuma od 30 odsto."

Odredba člana 18. pisana je po ugledu na član 10. Arbitražnih pravila UNCITRAL-a (2010) koji sadrži moderno rešenje za imenovanje arbitara u višestranačkoj arbitraži. Sadržina te odredbe pokazuje da su Beogradska pravila imala u vidu situaciju da se na tužilačkoj strani može pojaviti više lica, pa i veoma veliki broj lica („množina procesnih subjekata“). Prema tome, kolek-

111 Zakon o zaštiti potrošača, Službeni glasnik RS, br. 62/14 i 6/16, (u daljem tekstu: ZZP), član 5, tačka 30. Arbitraža se javlja kao jedan vid vansudskog rešavanja potrošačkih sporova.

112 Ibid., član 143. Detaljnije o ovoj odredbi vid. Stanivuković, M., 2013, pp. 240-241. 
tivna potrošačka arbitraža je moguća na osnovu Beogradskih pravila. Ukoliko bi, međutim, spor pokrenula jedna stranka ili grupa stranaka, a druge stranke $\mathrm{u}$ istoj situaciji bi kasnije želele da se pridruže, to ne bi bilo moguće bez saglasnosti tuženog (član 30). Što se tiče troškova, Beogradska pravila nude veoma povoljno rešenje, budući da ni veliki broj tužilaca ne može da dovede do povećanja arbitražnih troškova iznad 30 odsto od iznosa uobičajene tarife. Doduše, prema tarifi Beogradskog arbitražnog centra Sekretrijat može da naloži strankama da predujme dodatne iznose naknade za administrativne troškove i naknadu arbitrima u složenim predmetima, ali dodatni iznosi isto ne smeju da premaše 30 odsto od iznosa utvrđenog prema tarifi (član 7). Sekretarijat može, na osnovu člana 45. Beogradskih pravila, da naloži strankama da predujme eventualne dodatne materijalne troškove postupka, izdatke za procesne radnje i troškove putovanja i smeštaja arbitara.

Pravilnik Stalne arbitraže takođe predviđa rešenje za situaciju kada se u sporu pojavljuju kao tužioci više lica. Ukoliko tužioci ne mogu da se sporazumeju o izboru zajedničkog arbitra, njega imenuje predsednik Stalne arbitraže (član 19). Ovo rešenje je nešto nepovoljnije za tužioce jer omogućava tuženom da izabere arbitra, dok tužioci koji nastupaju kolektivno mogu biti lišeni tog prava. Načelo jednakosti stranaka u imenovanju arbitara je jedno od fundamentalnih načela arbitraže. ${ }^{113}$ Ipak, u većini slučajeva tužioci će biti organizovani kao grupa i njihov predstavnik ili zastupnik će na osnovu ugovora biti ovlašćen da u ime svih izabere arbitra. Pravilnik Stalne arbitraže takođe predviđa nepovoljnije rešenje i u odnosu na troškove. Ukoliko u arbitraži učestvuje više lica na tužilačkoj strani, za svako dodatno lice obračunava se uvećanje arbitražnih troškova za $10 \%$, koje nije maksimirano, tako da troškovi kolektivne arbitraže mogu značajno da narastu ako je broj tužilaca veliki (član 51. stav 2). Ako se u toku daljeg postupka pokaže da je prvobitno određen iznos nedovoljan da pokrije troškove arbitraže, predsednik arbitraže će odlučiti o naknadnim iznosima, u skladu sa tarifom. Takođe, ni ova odredba sadržana u članu 51. stav 4. ne predviđa maksimum troškova.

Iz svega što je rečeno sledi zaključak da je kolektivna arbitraža u potrošačkim sporovima moguća u Srbiji. Na pitanje da li je i poželjna, ne može se dati kategoričan odgovor. Razlozi koji ukazuju na nespojivost arbitraže i potrošačkih sporova možda su manje izražajni kada je u pitanju kolektivna arbitraža, ali nisu sasvim izbledeli. Uz primenu iskustava iz uporednog prava i korišćenje svih raspoloživih instrumenata koji sprečavaju zloupotrebu postupka i zloupotrebu prava, kolektivna akcija potrošača u arbitraži možda bi mogla u sadašnjim okolnostima i u sadašnjem trenutku da nadomesti nedostatak kolektivne zaštite u sudskom postupku. Utisak je ipak da ovaj američki izum nije u skladu sa evrop-

113 Francuski Kasacioni sud je u predmetu Dutco označio ovo načelo kao pitanje francuskog javnog poretka i odlučio da se stranka ne može odreći ovog prava pre početka spora. Cour de Cassation, Siemens AG and BKMI Industrienlagen GmbH v. Dutco Construction Company, Decision of 7 January 1992. 
skim, pa time i domaćim pravnim shvatanjima i tradicijom. ${ }^{114}$ Nije u duhu domaćeg pravnog sistema da zaštitu javnih interesa prepusti privatnoj inicijativi i privatnim mehanizmima rešavanja sporova. Ni arbitraža kao način rešavanja sporova nije toliko bliska i poznata privrednicima da bi do razvoja kolektivne arbitraže došlo spontano, korišćenjem velikog broja istovrsnih arbitražnih sporazuma. Privrednici u Srbiji i dalje veoma retko unose arbitražnu klauzulu u svoje ugovore sa potrošačima. Predviđamo da će Srbija pratiti vladajuće tendencije u Evropskoj uniji koje kolektivnu zaštitu prava potrošača vezuju za sudski i upravni postupak, uz mogućnost da se pre ili u toku tog postupka poravnanje traži medijacijom, a možda i nekim specifičnim oblicima arbitraže.

\section{ZAKLJUČAK}

U ovom članku opisan je fenomen više istovrsnih tužbenih zahteva u međunarodnoj arbitraži i njegova primenljivost za potrošačke sporove. Arbitražni postupak u kome je podneto više istovrsnih tužbenih zahteva često se naziva kolektivna arbitraža i može se svrstati u širi pojam višestranačke arbitraže. Mada je teško odrediti tačan broj tužbenih zahteva koji dovodi do transformacije postupka u kolektivnu arbitražu, čini se da do toga dolazi u onom trenutku kada broj tužbenih zahteva premaši meru koju bi jedan ograničen broj arbitara još uvek mogao da reši u razumnom roku, vođenjem klasičnog arbitražnog postupka za svaku od tužbi. Kao glavni razlozi za kumulaciju više zahteva u istom postupku navode se uštede u vremenu i troškovima, efikasnost, ujednačenost ishoda, pospešivanje poravnanja i, na kraju, bolji pristup pravdi. Kao razlozi protiv kolektivne arbitraže mogu se navesti: ograničavanje procesnih prava stranaka, nedostatak zakonskog i institucionalnog okvira, nekompatibilnost sa osnovnim načelima arbitraže i mogućnost zloupotreba. Činjenica da se arbitražni troškovi u kolektivnoj arbitraži raspoređuju i dele na veliki broj stranaka ima za posledicu da arbitražni postupak postaje dostupniji potrošačima. Kada se zbirno postave (kumuliraju) zahtevi male vrednosti, vrednost spora postaje dovoljno visoka da bi mogao da se finansira rad arbitra, lica koje će efikasno rešiti spor. Pretpostavka za efikasno odlučivanje je da su tužbeni zahtevi dovoljno slični da bi omogućili paušalno odlučivanje i da ne zahtevaju zaseban tretman. Ušteda u troškovima ostvaruje se po nekima i za tuženog, jer se tuženom omogućava da u jednom postupku koncentriše pravni i činjenični osnov svoje odbrane. Takođe, obezbeđuje se da arbitražni sud bude upoznat sa činjeničnim stanjem bez potrebe da ga u svakom novom slučaju advokati iznova "podučavaju“ o relevantnim činjenicama. Ipak, zaključak je ovog rada da kolektivna arbitraža nije u skladu sa domaćim pravnim shvatanjima i tradicijom. Uprkos tome što postoji potreba za pravnim postupkom kolektivne zaštite pojedinačnih interesa u slučaju nastupanja masovnih šteta, to u Srbiji verovatno neće biti kolektivna arbitraža.

114 British Institute of International and Comparative Law, ADR and Collective Redress, (https:// www.collectiveredress.org/collective-redress/alternative-adr, 28. 7. 2020). 


\section{LITERATURA}

1. Alexiev, A., National Report for Bulgaria, in: Bosman, L. (ed.), 2019, ICCA International Handbook on Commercial Arbitration, ICCA \& Kluwer Law International, Supplement No. 104.

2. Bates, D. M., 2003, A Consumer's Dream or Pandora’s Box: Is Arbitration a Viable Option for Cross-Border Consumer Disputes?, Fordham International Law Journal, Vol. 27, Issue 2.

3. Bélohlávek, A. J., 2013, Class Actions \& Arbitration Procedures - Czech Republic, in: Billiet, P., Hensler, D., Tzankova, I. (eds.), Class Actions \& Arbitration in the European Union.

4. Bosman, L., The ICCA International Handbook on Commercial Arbitration, Kluwer Arbitration, (http://www.kluwerarbitration.com/).

5. British Institute of International and Comparative Law, ADR and Collective Redress, (https://www.collectiveredress.org/collective-redress/alternative-adr).

6. Hanotiau, B., 2006, Complex Arbitrations - Multiparty, Multicontract, Multi-Issue and Class Actions, Kluwer Law International.

7. Heiskanen, V. A., Mass Claims in ICSID Arbitration, in: Kinnear, M., Fischer, G. R. et al. (eds.), 2015, Building International Investment Law: The First 50 Years of ICSID, Kluwer Law International.

8. Holtzmann, H. M., 2008, Mass Claims, Max Planck Encyclopedias of International Law [MPIL].

9. Janićijević, D., 2015, Višestranačke arbitraže - problemi i najnovija dešavanja, Facta universitatis - series: Law and Politics, Vol. 13, br. 1.

10. Janićijević, D., 2009, Arbitražni sporazum kao osnov arbitražnog rešavanja višestranih i kompleksnih sporova, Zbornik radova Pravnog fakulteta u Nišu, 54.

11. Janićijević, D., 2006, Rešavanje tzv. klasnih sporova u parničnom i arbitražnom postupku, Zbornik radova Pravnog fakulteta u Nišu, 47.

12. Kabra, R., Has Abaclat v Argentina left the ICSID with a 'mass'ive problem?, in: Park, W. W. (ed.), 2015, Arbitration International, Oxford University Press, Vol. 31, Issue 3.

13. Karanikić Mirić, M., 2014, Kolektivna zaštita potrošača u srpskom pravu, Anali Pravnog fakulteta Univerziteta u Zenici.

14. Klauser, A., 2019, The Essentials of Class Action in Austria, Lexology, (https://www. lexology.com/library/detail.aspx?g=91e0cfc9-db17-467b-aeae-3ffbd9802102).

15. Martinez, J., 2014, La Class action „à la française“, Le Petit Juriste, (https://www.lepetitjuriste.fr/la-class-action-a-la-francaise/).

16. Olík, M., National Report for the Czech Republic, in: Bosman, L. (ed.), 2020, ICCA International Handbook on Commercial Arbitration, ICCA \& Kluwer Law International, Supplement No. 109.

17. Ostrager, B. R., Thomas, P. C., Smit, R. H., 1999, Andersen v. Andersen: The Claimant's Perspective, The American Review of International Arbitration, Vol. 10, No. 4.

18. Pusey, A., 2016, April 16, 1947: Deadly ship explosions lead to first class action, $A B A$ Journal, (https://www.abajournal.com/magazine/article/april_16_1947_deadly_ship_ explosions_lead_to_first_class_action).

19. Poudret, J. F., Besson, S., Berti, S. V., Fonti, A., 2007, Comparative law of international arbitration, Thomson Sweet \& Maxwell, $2^{\text {nd }}$ edition. 
20. Radicati di Brozolo, L. G., Ponzano, F., Representative Aspects of „Mass Claim“ Proceedings in Investor-State Arbitration, in: Hanotiau, B., Schwartz, E. A. (eds.), 2016, Class and Group Actions in Arbitration, Dossiers of the ICC Institute of World Business Law, ICC Pub. No. 771, Vol. 14.

21. Ross, A., 2018, Czech Republic hits back at reports of solar loss, Global Arbitration Review, p. 2, (https://globalarbitrationreview.com/article/1153107/czech-republichits-back-at-reports-of-solar-loss).

22. Rule, C., Rogers, V., Del Duca, L. F., 2010, Designing a Global Consumer Online Dispute Resolution (ODR) System for Cross-Border Small Value - High Volume Claims - OAS Developments, Uniform Commercial Code Law Journal, Vol. 42, (https:// papers.ssrn.com/sol3/papers.cfm?abstract_id=1635463).

23. Stanivuković, M., 2014, Međunarodna arbitraža, Službeni glasnik.

24. Stanivuković, M., 2020, Hungaro-Yugoslav Mixed Arbitral Tribunal (u štampi).

25. Stanivuković, M., Arbitration: Is it a viable option for resolution of consumer disputes in Serbia?, in: Taboroši S., Bourgoignie, T., Jovanić, T. (eds.), 2013, Strengthening Consumer Protection in Serbia, Pravni fakultet Univerziteta u Beogradu.

26. Strong, S. I., 2019, Collective Redress Arbitration in the European Union, in: International Arbitration and EU Law, Edward Elgar Publishing Ltd (anticipated 2020), (https://papers.ssrn.com/sol3/papers.cfm?abstract_id=3396138).

27. Strong, S. I., 2013, Class, Mass, and Collective Arbitration in National and International Law, Oxford University Press.

28. Thomson, D., 2016, Argentina settles Abaclat sovereign bond claim, Global Arbitration Review, (https://globalarbitrationreview.com/article/1035101/argentina-settles-abaclat-sovereign-bond-claim).

29. Uzelac, A., National Report for Croatia, in: Bosman, L. (ed.), 2020, ICCA International Handbook on Commercial Arbitration, ICCA \& Kluwer Law International, Supplement No. 109.

30. Cukavac, M., 2003, Arbitraža sa više stranaka, Pravo i privreda, Vol. 40, br. 1-4.

\section{PROPISI}

1. Real Decreto-ley 231/2008 de 15 de febrero, por el que se regula el Sistema Arbitral de Consumo, Boletín Oficial Del Estado, lunes 25 de febrero de 2008, Número 48, Página 11072, arts. 56-62.

2. La loi $n^{\circ} 2014-344$ du 17 mars 2014 relative à la consommation, (https://www.legifrance.gouv.fr/affichTexte.do?cidTexte=JORFTEXT000028738036\&dateTexte $=\&$ cate gorieLien=id\#JORFSCTA000028738116).

3. Arbitration Act 1996, (https://www.legislation.gov.uk/ukpga/1996/23/contents).

4. Zakon o arbitraži, Sl. glasnik RS, br. 46/06.

5. The Council of the European Communities, Council Directive 93/13/EEC of 5 April 1993 on unfair terms in consumer contracts, Annex, Section 1, Item q, Official Journal of the European Communities, L 95/29, 21 April 1993.

6. Zakon o zaštiti potrošača, Službeni glasnik RS, br. 62/14 i 6/16. 


\title{
COLLECTIVE REDRESS IN INTERNATIONAL ARBITRATION AND ITS RELEVANCE FOR CONSUMER DISPUTES
}

\author{
Maja Stanivuković
}

\begin{abstract}
SUMMARY
The topic of this article is collective redress in international arbitration which is relevant for consumer disputes. The collective action in arbitration belongs to the broader category of multi-party arbitrations. Although it is difficult to determine the number of claims that transforms the procedure into a collective arbitration it seems that this occurs at the moment when the number of claims surpasses a measure that a limited number of arbitrators could still handle within a reasonable time, by conducting classic bilateral arbitration proceedings. The main reasons that are cited in favor of allowing multiple claims in the same arbitral procedure are: saving time and cost, efficiency, uniformity of outcomes, improved access to justice and fostering settlements. On the other hand, the following reasons are put forward against collective arbitration: limitation of procedural rights of the parties, incompatibility of collective redress with the main tenets of arbitration, the lack of statutory and institutional framework and great potential for abuse. There is no doubt that there is a need for a collective consumer redress mechanism in Serbia. However, after examining pros and cons, the author concludes that this mechanism will probably not be collective arbitration.
\end{abstract}

Key words: arbitration, collective redress, consumer disputes, investment arbitration. 